\begin{tabular}{|c|l|}
\hline Title & Molecular systematics of the bark lice infraorder Caeciliusetae (Insecta: Psocodea) \\
\hline Author(s) & YOSHIZA WA, KAZUNORI; MOCKFORD, EDW A RD L.; JOH NSO N, KEV IN P. \\
\hline Citation & $\begin{array}{l}\text { Systematic Entomology, 39(2), 279-285 } \\
\text { https:/doi.org/L0.1111/syen.12054 }\end{array}$ \\
\hline Issue Date & 201404 \\
\hline Doc URL & http://hdl.handle.net/2115/58545 \\
\hline Rights & The definitive version is available at www.blackwell-synergy.com \\
\hline Type & article (author version) \\
\hline File Information & 2014Cae.pdf \\
\hline
\end{tabular}

Instructions for use 


\title{
Molecular Systematics of the bark lice infraorder Caeciliusetae (Insecta: Psocodea)
}

\author{
Kazunori Yoshizawa ${ }^{1}$, Edward L. Mockford ${ }^{2}$, and Kevin P. Johnson ${ }^{3}$ \\ 1Systematic Entomology, Hokkaido University, Sapporo, Japan \\ 2Department of Biology, Illinois State University, Bloomington, Illinois, USA \\ 3Illinois Natural History Survey, University of Illinois, Champaign, Illinois, USA
}

Corresponding Author: Kevin P. Johnson

\begin{abstract}
The phylogenetic relationships of bark lice and parasitic lice (Insecta: Psocodea) have been studied in a number of recent molecular phylogenetic analyses based on DNA sequences. Many of these studies have focused on the position of parasitic lice within the free-living bark lice. However, fewer such studies have examined the relationships among major groups of free-living bark lice and their implications for classification. In this study we focus on the infraorder Caeciliusetae, a large group of bark lice ( 1000 species) within the suborder Psocomorpha.

Using sequences of two mitochondrial and two nuclear genes, we estimated the phylogeny for relationships among the five recognized families within the infraorder Caeciliusetae. Based on the results, the monophyly of two families is strongly supported, Stenopsocidae and Dasydemellidae, as well as a sister relationship between these two families. Monophyly of the larger families Amphipsocidae and Caeciliusidae was not supported, though the causes of this were the positions of two distinct subfamilies (Paracaeciliinae and Calocaeciliinae). The monophyly of the final family Asiopsocidae could not be tested because it was only sampled by one species.

Based on these results and consideration of morphological characters, we propose a new classification for the Caeciliusetae, recognizing six families: Amphipsocidae, Stenopsocidae, Dasydemellidae, Asiopsocidae, Paracaeciliidae, and Caeciliusidae. We expect this new classification will stabilize the higher level taxonomy of this group and help to identify groups in need of further work among these insects.
\end{abstract}




\section{Introduction}

A number of previous phylogenetic studies have focused on Psocodea, an insect order containing over 10,000 species of bark lice and parasitic lice. Prior work has shown that parasitic lice are phylogenetically derived from free-living bark lice (Lyal, 1985; Yoshizawa \& Johnson, 2003, 2010; Johnson et al., 2004). Within bark lice, formerly classified as the order Psocoptera, three suborders are traditionally recognized: Trogiomorpha, Troctomorpha, and Psocomorpha (Lienhard \& Smithers, 2002). The phylogenetic relationships among the first of these, Trogiomorpha, have been examined in detail (Yoshizawa et al., 2006) and a new classification proposed. The second, Troctomorpha, is likely to be paraphyletic with respect to parasitic lice (Phthiraptera) (Johnson et al., 2004), yet remains to be investigated in detail. The phylogeny of the third and largest suborder, Psocomorpha ( $>4000$ species), has received some attention using molecular data (Johnson \& Mockford, 2003; Johnson et al., 2004; Yoshizawa \& Johnson, 2010); however, considerable work is needed before an exhaustive new classification system can be proposed.

The goal of the present study is to understand the phylogenetic relationships within a major clade of the Psocomorpha, the infraorder Caeciliusetae, which contains around 1000 species. First recognized formally as a taxon by Pearman (1936), the group underwent important changes with removal of what is currently the family Calopsocidae by Roesler (1944), which was followed by Smithers (1967), and the addition of the family Asiopsocidae by Mockford and Gracia Aldrete (1976). Monophyly of the infraorder Caeciliusetae has been supported on the basis of both morphological (Badonnel, 1951; Mockford \& Garcia Aldrete, 1976; Mockford, 1993; Lienhard, 1998; Yoshizawa, 2002) and molecular (Johnson \& Mockford, 2003; Johnson et al., 2004; Yoshizawa \& Johnson, 2010) characters. The majority of species are yellowish in color and found on dead or dying leaves, although there is considerable variation in the group in morphology and habits (Figure 1). No formal morphological analysis has been performed for the entire infraorder. Current classification (Lienhard \& Smithers, 2002; see also Table 1) includes five families: Asiopsocidae, Caeciliusidae, Stenopsocidae, Amphipsocidae, and Dasydemellidae. Mockford (2000) provided an extensive revision of Caeciliusidae, the largest family in the infraorder. This family was divided into four subfamilies and the largest, Caeciliusinae, is further divided into five tribes (Table 1).

Here we evaluate the current classification scheme (Lienhard \& Smithers, 2002) for the bark louse infraorder Caeciliusetae using molecular phylogenetic data from two mitochondrial and two nuclear genes. Taxon sampling was aimed at testing the monophyly and phylogenetic relationships among families. We are able to assess finer scale classification to a lesser extent. Based on our results, we propose a new classification scheme for this infraorder and evaluate this classification with respect to morphological characters.

\section{Materials and Methods}

Samples were obtained from all extant families of Caeciliusetae and a variety of outgroup taxa throughout the suborder Psocomorpha, focusing on taxa previously identified to be among the closer relatives of Caeciliusetae (Table 2). Methods of DNA extraction PCR amplification, and sequencing followed Johnson \& Mockford (2003) and Johnson et al. (2004). We sequenced portions of the mitochondrial 16S and 12S rDNA genes and the nuclear 18S rDNA and histone 3 genes (GenBank Accession pending). Primers included 16Sar-16Sbr for 16S (Simon et al., 1994), 12Sai-12Sbi for 12S (Simon et al., 1994), Ns1-Ns2a, 18Sai-18Sbi, and Ns5a-Ns8P for 18S (Johnson et al., 2004), and H3AF-H3AR for histone 3 (Colgan et al., 1998).

Alignment of the protein-coding histone 3 gene was straightforward and done manually. Ribosomal DNA was aligned according to secondary structure models as described in detail by Yoshizawa \& Johnson (2003) for 12S 
and 16S and Johnson et al. (2004) for 18S. Ambiguously aligned regions were selected manually and excluded from the analyses. Aligned data in nexus format is available as Supplementary data or at http://psocodea.org/ kazu/data/Caeciliusetaae/.

Using these aligned sequences, we conducted combined maximum likelihood and partitioned Bayesian analyses. For ML analyses, we used PAUP* (Swofford, 2002) with TBR branch swapping and a NJ starting tree. The best fit substitution model was estimated using hierarchical likelihood ratio tests (hLRT) as implemented in Modeltest 3.7 (Posada \& Crandall, 1998) and the GTR $+\mathrm{I}+\mathrm{G}$ model was selected. We also performed 100 ML bootstrap pseudoreplicates in PAUP* using the same search conditions. For Bayesian analysis, we separated characters into 6 partitions $(18 \mathrm{~S}, 12 \mathrm{~S}, 16 \mathrm{~S}$, and the three codon positions of the histone 3 gene). The best fit model was estimated independently for each partition using hLRTs as implemented in MrModeltest (Nylander 2004), resulting in 18S and 16S $(\mathrm{GTR}+\mathrm{I}+\mathrm{G}), 12 \mathrm{~S}(\mathrm{GTR}+\mathrm{G})$, histone 3 first position $(\mathrm{SYM}+\mathrm{G})$, histone 3 second position $(\mathrm{JC})$, and histone 3 third position $(\mathrm{GTR}+\mathrm{G})$. Detailed parameters and commands for ML and Bayesian analyses are described in the Supplementary data matrix. Bayesian analysis was conducted in MrBayes (Ronquist \& Huelsenbeck, 2003) with two runs of four chains each for 2,000,000 generations and trees sampled every 1000 generations. The first $50 \%$ of trees were discarded as a burnin, and a $50 \%$ majority consensus tree of the remainingtrees was used to calculate posterior probabilities.

\section{Results}

The phylogenetic trees resulting from maximum likelihood and Bayesian analyses of the four gene regions were well resolved and some key branches received strong support (Figure 2). These trees were nearly identical except for minor rearrangements of weakly supported branches. Both maximum likelihood and Bayesian analysis supported monophyly of Caeciliusetae (100\% bootstrap and Bayesian posterior probability). Monophyly of the families Dasydemellidae and Stenopsocidae were strongly supported (100\%) in all analyses. The family Asiopsocidae was only represented by a single species, so monophyly of this family could not be tested.

Monophyly of Amphipsocidae is not recovered, with the representative of the monogeneric subfamily Calocaeciliinae (Calocaecilius Mockford) being embedded within the Caeciliusidae. However, the five representatives of the other subfamily Amphipsocinae formed a monophyletic group (100\% support). Similarly, monophyly of the family Caeciliusidae was also not supported, both because of the placement of Calocaecilius and because Asiopsocidae was recovered as the sister taxon to a clade of four species of the subfamily Paracaeciliinae. Monophyly of the remainder of Caeciliusidae (inclusive of Calocaecilius) was generally supported ( $69 \%$ bootstrap, $100 \%$ Bayesian posterior).

The families Dasydemellidae and Stenopsocidae were recovered as sister taxa with strong support $(100 \%)$. However, other than the sister relationship between Asiopsocidae and the Paracaeciliinae, the relationships among the remainder of the families and major clades were less clear and generally weakly supported. The family Asiopsocidae does not appear to be sister to the remainder of Caeciliusetae and thus does not merit recognition as a distinct superfamily.

Whiletaxon sampling does not permit an exhaustive evaluation of subfamilial classification schemes, some conclusions can be drawn from the phylogenetic results. First, within the Amphipsocinae, monophyly of the largest tribe, Amphipsocini is not supported because of a sister relationship between Polypsocus Hagen (Polypsocini) and Tagalopsocus (Amphipsocini), exclusive of the other sampled members of Amphipsocini (Amphiposcus Smithers and Taeniostigma Enderlein). Within the Stenopsocidae, the genus Stenopsocus Hagen 
appears to be paraphyletic. The subfamily Paracaeciliinae appears to form a clade well separated from other groups, and within this clade, the genus Enderleinella Badonnel is not monophyletic.

Within the remainder of Caeciliusidae there is generally insufficient taxon sampling to assess the detailed tribal classification of Mockford (2000) and Lienhard \& Smithers (2002). However, the genus Valenzuela, with five species sampled is strongly supported to be monophyletic and the sister relationship with this genus and Coryphosmila Enderlein provides support for the tribe Coryphacini, as well as the separation of Valenzuela Navas from Caecilius Curtis (Mockford, 2000). The genus Fuelleborniella Enderlein has previously been placed in a separate subfamily Fuelleborniellinae, together with Smithersiella Badonnel and Ypsiloneura Pearman. While its position in the tree is somewhat unclear, Fuelleborniella does not appear to be particularly distinct and the best estimates place it inside the Caeciliusinae, suggesting the subfamily Fuelleborniellinae may not merit recognition.

\section{Discussion}

A molecular phylogenetic analysis of two mitochondrial and two nuclear genes provides new insights into the phylogenetic relationships and classification of the bark louse infraorder Caeciliusetae. Monophyly of Caeciliusetae continues to receive strong support on the basis of molecular analysis. This infraorder also has strong support based on morphological characters (Yoshizawa, 2002) and we expect that this group will continue to be robust to additional taxon sampling. In general, many of the previously recognized groups within Caeciliusetae are supported. However, there are also several notableexceptions.

The monophyly of Dasydemellidae is noteworthy, because it has not consistently been recognized as a distinct family (e.g. Yoshizawa, 2001, 2002). Dasydemellidae was first recognized as a taxon by Mockford (1978), who regarded it as a subfamily of Amphipsocidae with the most important defining characters being 1) a broad and relatively flat lacinial tip, 2) setae of hindwings greatly reduced or absent, 3) sheath of the spermathecal duct short and broad, 4) the third ventral abdominal vesicle (v3) well sclerotized, and 5) the nymphal duplex spine and associated setae of the paraproct retained in adults of both sexes. In addition, a prior analysis of morphological characters (Yoshizawa, 2002) did not recover a sister relationship between Dasydemellidae and Stenopsocidae, while this is one of the most strongly supported results of our molecular analysis. Dasydemellidae and Stenopsocidae possess several morphological characters in common. These include 1) the reduction to near absence of hindwing setae, 2) relatively large body size, 3) a notable common stem of ventral abdominal vesicles v2 and v3, 4) v3 well sclerotized, and 5) a short and broad sheath of the spermathecal duct.

Even though it has been the subject of an extensive study and classification system (Mockford, 2000; Lienhard \& Smithers, 2002), the large family Caeciliusidae still appears to be in need of additional evaluation from a morphological perspective and some reclassification. In particular, there is strong support from the molecular data for the separation of the subfamily Paracaeciliinae and even elevation to a separate family. There is also substantial support from morphological characters for the monophyly of Paracaeciliidae, including 1) distal inner labral sensilla consisting of three placoids alternating with four trichoids (type 3 of Mockford, 2000); 2) cell $\mathrm{R}_{5}$ of forewing scarcely, if at all, constricted beyond its base; 3) usually with three ventral abdominal vesicles (Mockfordiella Badonnel, with two is the only exception); 4) endophallus bilobed (undivided in Mockfordiella); and 5) neck of spermathecal sac either wide throughout or widened at its junction with sheath (spermatheca absent in Mockfordiella). 
The placement of the amphipsocid genus Calocaecilius within Caeciliusidae suggests that Caeciliusidae should be redefined to include Calocaeciliinae. Calocaecilius, partly because of its presumed beetle mimicry (Mockford, 1974), stands apart morphologically from the rest of Caeciliusidae. Its position within Caeciliusidae is not well resolved and it could possibly be sister to the remainder of the family. In fact, the relationships among the redefined Caeciliusidae are not well supported, so it is difficult to assess the subfamilial classification scheme of Mockford (2000) and Lienhard \& Smithers (2002). Certainly the sister relationship between Valenzuela and Coryphosmila, both in the tribe Coryphacini, support elements of this classification. However, both further phylogenetic support and additional taxon sampling are needed before an exhaustive reclassification of Caeciliusidae can beattempted on the basis of molecular data.

In conclusion, we propose a new family level classification scheme for the Caeciliusetae based on our analysis of molecular data and reevaluation of morphological characters. This scheme abandons superfamilies and classifies the infraorder into six families: Amphipsocidae, Stenopsocidae, Dasydemellidae, Asiopsocidae, Paracaeciliidae, and Caeciliusidae. We do not revise the existing classification below family (Lienhard \& Smithers, 2002) until further work on the group is performed, though it is likely that some rearrangement will be needed.

\section{Key to the Families of Caeciliusetae}

1. With 5-7 distal labral sensilla. Cell R5 in forewing lacking a median constriction or inward curvature of vein Rs 2

- With not more than 5 distal labral sensilla. Cell R5 in forewing with a median constriction or at least a median inward curvature of vein Rs. .3

2. Generally 3 ventral abdominal vesicles present (see Mockford, 1993, Fig. 113); v3 clearly enclosed in widened base of $\mathrm{v} 2+3$ Family Paracaeciliidae

- Ventral abdominal vesicles absent; $\mathrm{v} 3$, when present, a distinct lateral lobe on base of v2

\section{Family Asiopsocidae}

3. In hindwing, marginal setae restricted to cell $\mathrm{R} 3$ or none...................4

In hindwing, marginal setae around most of wing except basal half of fore margin.........5

4. Forewing with pterostigma-rs crossvein and m-cula crossvein. Nymphal paraproctal duplex spine and associated setae not retained in adults.

Family

\section{Stenopsocidae}

Forewing lacking pterostigma-rs crossvein and m-cula crossvein. Nymphal paraproctal duplex spine and associated setae retained in adults (see Mockford, 1978, Fig. 23)

\section{.Family Dasydemellidae}

5. Basal $\mathrm{R}$ and $\mathrm{M}-\mathrm{Cu}$ veins of forewing and often more distal veins with more than one rank of setae; In hindwing, Rs and distal M veins bearing setae; v3 a small lobe on base of v2 lacking a seta

\section{.Family Amphipsocidae}

Basal $\mathrm{R}$ and $\mathrm{M}-\mathrm{Cu}$ veins of forewing, as well as other veins, with only one rank of setae; in hindwing all veins lacking setae; $\mathrm{v} 3$ generally a major lobe on base of $\mathrm{v} 2$ with one or more setae. Family

\section{Caeciliusidae}




\section{Acknowledgements}

This work was supported by NSF grants DEB-0612938 to KPJ and JSPS grant 18770058 and 1877058 to KY. KY's field work to Malaysia and Nepal were supported by JSPS grants 14255016 and 17255001 (project leader: O. Yata at Kyushu University). KY thanks A.B. Idris, H. Kojima, S. Nomura, I. Ohshima, M. Shrestha and N. Takahashi for help in the field. We thank T. Muroi, G. Svenson, and M. Whiting for assistance in obtaining samples.

\section{References}

Badonnel, A. (1951) Psocopteres. In Grasse, P.-P. Traite de Zoologie. Paris. Vol. 10, fasc. 2: 1301 - 1340 , figs. $1135-1170$.

Buckley, T. R., Simon, C., Flook, P. K. \& Misof, B. (2000) Secondary structure and conserved motifs of the frequently sequenced domains IV and V of the insect mitochondrial large subunit rRNA gene. Insect Molecular Biology 9, 565-580.

Colgan, D. J., McLauchlan, A., Wilson, G. D. F., Livingston, S. P., Edgecombe, G. D., Macaranas, J., Cassis, G. \& Gray, M. R. (1998). Histone H3 and U2 sn RNA DNA sequences and arthropod molecular evolution. Australian Journal of Zoology 46, 419-437.

Hickson, R. E., Simon, C. \& Perrey, S. W. (2000) The performance of several multiple sequence alignment programs in relation to secondary-structure features for a rRNA sequence. Molecular Biology and Evolution 17, 530-539.

Johnson, K. P. \& Mockford, E. L. (2003) Molecular systematics of Psocomorpha (Insecta: Psocoptera). Systematic Entomology 28, 409-416.

Johnson, K. P., Yoshizawa, K. \& Smith, V. S. (2004) Multiple origins of parasitism in lice. Proceedings of the Royal Society of London B 271, 1771-1776.

Kjer, K. M. (2004) Aligned 18S and insect phylogeny. Systematic Biology 53, 506-514.

Lienhard, C. (1998) Psocopteres euro-mediterraneens. Faune de France 83.

Lienhard, C. \& Smithers, C. N. (2002) Psocoptera (Insecta): World Catalogue and Bibliography. Intrumenta Biodiversitatis V, Muséum d'Histoire naturelle, Geneva.

Lyal, C. H. C. (1985) Phylogeny and classification of the Psocodea, with particular reference to the lice (Psocodea: Phthiraptera). Systematic Entomology 10, 145-165.

Mockford, E. L. (1974) New genus and species of Amphipsocidae from southeastern Asia (Psocoptera). Entomological News 85, 155 - 158.

Mockford, E. L. (1978) A generic classification of the family Amphipsocidae (Psocoptera: Caecilietae). Transactions of the American Entomological Society 104, 139 - 190.

Mockford, E. L. (1993) North American Psocoptera (Insecta). Flora and Fauna Handbook 10.

Mockford, E. L. (2000) A classification of the psocopteran family Caeciliusidae (Caeciliidae Auct.). Transactions of the American Entomological Society 125, 325-417.

Mockford, E. L. \& Garcia Aldrete, A. N. (1976) A new species and notes on the taxonomic position of Asiopsocus Gunther (Psocoptera). Southwestern Naturalist 21, 335 - 346.

Nylander, J. A. A. (2004) MrModeltest v2. Program distributed by the author. Evolutionary Biology Centre, Uppsala Univeristy.

Pearman, J. V. (1936) The taxonomy of the Psocoptera: preliminary sketch. Proceedings of the Royal Entomological Society of London (B) 5, 58 - 62. 
Posada, D. \& Crandall, K. A. (1998) Modeltest: testing the model of DNA substitution. Bioinformatics 14, 817-818.

Roesler, R. (1944) Die Gattungen der Copeognathen. Stettiner Entomologische Zeitung 104, 1-14.

Ronquist, F. \& Huelsenbeck, J. P.(2003) MrBayes3: Bayesian phylogenetic inference under mixed models. Bioinformatics 19, 1572-1574.

Simon, C., Frati, F., Beckenbach, A., Crespi, B., Liu, H. \& Flook, P. (1994) Evolution, weighting, and phylogenetic utility of mitochondrial gene sequences and a comparison of conserved polymerase chain reaction primers. Annals of the Entomological Society of America 87, 81-144.

Smithers, C. N. (1967) On the relationships of the Calopsocidae (Psocoptera). Journal of the Australian Entomological Society 6, 61 - 64.

Swofford, D. L. (2002) PAUP*: Phylogenetic Analysis Using Parsimony (*and other methods). Version 4. Sinauer Assoc., Sunderland, MA.

Yoshizawa, K. (2001) Systematic study of Amphipsocidae in Japan (Psocodea: "Psocoptera": Caeciliusetae), with comments on higher classification within the family. Insecta Matsumurana, New Series 58, $1-25$.

Yoshizawa, K. (2002) Phylogeny and higher classification of suborder Psocomorpha (Insecta: Psocodea: "Psocoptera"). Zoological Journal of the Linnean Society 136, 371-400.

Yoshizawa, K. \& Johnson, K. P. (2003) Phylogenetic position of Phthiraptera (Insecta: Paraneoptera) and elevated rate of evolution in mitochondrial 12S and 16S rDNA. MolecularPhylogenetics and Evolution 29, 102-114.

Yoshizawa, K. \& Johnson, K. P. (2010) How stable is the "Polyphyly of Lice" hypothesis (Insecta: Psocodea)?: A comparison of phylogenetic signal in multiple genes. Molecular Phylogenetics and Evolution 55, 939-951.

Yoshizawa, K., Lienhard, C. \& Johnson, K. P. (2006) Molecular systematics of the suborder Trogiomorpha (Insecta: Psocodea: "Psocoptera”). Zoological Journal of the Linnean Society 146, 287-299. 


\section{Figure Legends}

Figure 1. Photographs of representative species of Caeciliusetae included in the study. A) Valenzuela badiostigma, B) Paracaecilius japanus, C) Graphopsocus cruciatus, D) Matsumuraiella radiopicta.

Figure 2. Phylogenetic tree resulting from maximum likelihood analyses of the $18 \mathrm{~S}$ rDNA, histone 3 , $16 \mathrm{~S}$ rDNA, and 12S rDNA genes. Numbers associated with each branch indicate ML bootstrap / Bayesian posterior probabilities. Sidebars on right are classification according to Lienhard and Smithers (2002), while those on left reflect the revised classification proposed in the current study. 
Table 1 Classification of Caeciliusetae Following Lienhard and Smithers (2002)

Superfamily: Asiopsocoidea

Family: Asiopsocidae

Superfamily: Caeciliusoidea

Family: Caeciliusidae

Subfamily: Caeciliusinae

Tribe: Caeciliusini

Tribe: Kodamaiini

Tribe: Maoripsocini

Tribe: Coryphacini

Tribe: Epicaeciliini

Subfamily: Aphyopsocinae

Subfamily: Paracaeciliinae

Subfamily: Fuelleborniellinae

Family: Stenopsocidae

Family: Amphipsocidae

Subfamily: Amphipsocinae

Tribe: Kolbiini

Tribe: Schizopechini

Tribe: Capillopsocini

Tribe: Dasypsocini

Tribe: Polypsocini

Tribe: Amphipsocini

Subfamily: Calocaeciliinae

Family: Dasydemellidae

Subfamily: Dasydemellinae

Subfamily: Ptenopsilinae 
Table 2. Samples Included in Study

$\begin{aligned} & \text { Species } \\
& \text { Locality }\end{aligned}$
$\begin{aligned} & \text { Ingroup } \\
& \text { Asiopsocidae }\end{aligned}$
\begin{tabular}{|l|l|l|l|l|l|l|}
\hline $\begin{array}{l}\text { Asiopsocus } \\
\text { sonorensis }\end{array}$ & USA & $\begin{array}{l}\text { Assp. } \\
11.17 .2003 .3\end{array}$ & AY63048 & GU56933 & GU56920 & AB85691 \\
\hline
\end{tabular}

\section{Dasydemellidae}

\section{Dasydemelliinae}

\section{Ptenopsilinae}

Ptenopsilla sp.

Chile

Chile

KY243

\begin{tabular}{|l|l|l|}
\hline Dasydemella sp. & $\begin{array}{l}\text { Malays } \\
\text { ia }\end{array}$ & KY380 \\
\hline $\begin{array}{l}\text { Teliapsocus } \\
\text { conterminus }\end{array}$ & USA & Tecon.3.2.2004.1 \\
\hline $\begin{array}{l}\text { Matsumuraiella } \\
\text { radiopicta }\end{array}$ & Japan & KY236 \\
\hline
\end{tabular}

\section{Stenopsocidae}

Graphopsocus

cruciatus

Malostenopsocus sp.

Stenopsocus

aphidiformis

Stenopsocus

nigricellus

\begin{tabular}{|l|l|l|l|} 
AB85695 & AB85697 & AB85694 & AB85692 \\
5 & 6 & 0 & 0 \\
\hline AB85695 & AB85697 & AB85693 & missing \\
1 & 2 & 6 & \\
\hline AY63049 & DQ10479 & DQ10477 & AB85691 \\
3 & 7 & 0 & 2 \\
\hline
\end{tabular}

\begin{tabular}{l|l|l|l} 
AY63049 & missing & AB85692 & AB85689 \\
4 & & 9 & 9 \\
\hline
\end{tabular}

\begin{tabular}{|l|l|l|l|} 
AY63049 & GU56933 & GU56921 & AY27530 \\
0 & 6 & 1 & 6 \\
\hline AB85695 & AB85697 & AB85693 & AB85691 \\
0 & 1 & 5 & 5 \\
\hline AY63049 & GU56933 & GU56921 & AB85691 \\
\hline 1 & 7 & 2 & 0 \\
\hline AY63049 & GU56933 & GU56921 & AB85691 \\
\hline 2 & 8 & 3 & 1 \\
\hline
\end{tabular}

\section{Amphipsocidae}

Amphipsocinae

\begin{tabular}{|c|c|c|c|c|c|c|}
\hline \multicolumn{7}{|c|}{ Amphipsocini } \\
\hline $\begin{array}{l}\text { Amphipsocus } \\
\text { japonicus }\end{array}$ & Japan & KY211 & $\begin{array}{l}\text { AF63048 } \\
9\end{array}$ & $\begin{array}{l}\text { GU56933 } \\
1\end{array}$ & $\begin{array}{l}\text { GU56920 } \\
6\end{array}$ & $\begin{array}{l}\text { AB85690 } \\
9\end{array}$ \\
\hline $\begin{array}{l}\text { Taeniostigma } \\
\text { elongatum }\end{array}$ & $\begin{array}{l}\text { Malays } \\
\text { ia }\end{array}$ & KY221 & $\begin{array}{l}\text { AY } 63048 \\
6\end{array}$ & $\begin{array}{l}\text { GU56933 } \\
5\end{array}$ & $\begin{array}{l}\text { GU56921 } \\
0\end{array}$ & $\begin{array}{l}\text { AB } 85690 \\
7\end{array}$ \\
\hline Tagalopsocus sp. & $\begin{array}{l}\text { Malays } \\
\text { ia }\end{array}$ & KY257 & $\begin{array}{l}\mathrm{AB} 85694 \\
9\end{array}$ & $\begin{array}{l}\mathrm{AB} 85696 \\
8\end{array}$ & $\begin{array}{l}\mathrm{AB} 85693 \\
2\end{array}$ & $\begin{array}{l}\text { AB } 85690 \\
2\end{array}$ \\
\hline \multicolumn{7}{|l|}{ Kolbiini } \\
\hline Kolbia fusconervosa & Japan & KY208 & $\begin{array}{l}\text { AY } 63048 \\
7\end{array}$ & $\begin{array}{l}\text { GU56933 } \\
3\end{array}$ & $\begin{array}{l}\text { GU56920 } \\
8\end{array}$ & $\begin{array}{l}\text { AB85690 } \\
8\end{array}$ \\
\hline \multicolumn{7}{|l|}{ Polypsocini } \\
\hline Polypsocus corruptus & USA & $\begin{array}{l}\text { Pocor. } \\
8.31 .2001 .6\end{array}$ & $\begin{array}{l}\text { AY } 63048 \\
8\end{array}$ & $\begin{array}{l}\text { GU56933 } \\
4\end{array}$ & $\begin{array}{l}\text { GU56920 } \\
9\end{array}$ & $\begin{array}{l}\text { AY27530 } \\
9\end{array}$ \\
\hline \multicolumn{7}{|l|}{ Calocaeciliinae } \\
\hline $\begin{array}{l}\text { Calocaecilius } \\
\text { decipiens }\end{array}$ & $\begin{array}{l}\text { Malays } \\
\text { ia }\end{array}$ & KY201 & $\begin{array}{l}\text { AY63048 } \\
5\end{array}$ & $\begin{array}{l}\text { GU56933 } \\
2\end{array}$ & $\begin{array}{l}\text { GU56920 } \\
7\end{array}$ & $\begin{array}{l}\text { AB85690 } \\
6\end{array}$ \\
\hline
\end{tabular}




\section{Caeciliusinae}

\begin{tabular}{|c|c|c|c|c|c|c|}
\hline \multicolumn{7}{|c|}{ Caeciliusini } \\
\hline Caecilius fuscopterus & Japan & KY227 & $\begin{array}{l}\text { AY } 63048 \\
4\end{array}$ & $\begin{array}{l}\text { AB85696 } \\
9\end{array}$ & $\begin{array}{l}\text { AB85693 } \\
3\end{array}$ & $\begin{array}{l}\mathrm{AB} 85690 \\
5\end{array}$ \\
\hline Caecilius sp. & Nepal & KY403 & $\begin{array}{l}\text { AB85696 } \\
0\end{array}$ & $\begin{array}{l}\text { AB85698 } \\
1\end{array}$ & missing & missing \\
\hline Caecilius sp. & $\begin{array}{l}\text { Malays } \\
\text { ia }\end{array}$ & KY389 & $\begin{array}{l}\text { AB85698 } \\
9\end{array}$ & $\begin{array}{l}\text { AB85698 } \\
0\end{array}$ & $\begin{array}{l}\text { AB85694 } \\
4\end{array}$ & $\begin{array}{l}\text { AB85692 } \\
4\end{array}$ \\
\hline $\begin{array}{l}\text { Dypsocus } \\
\text { coleoptratus }\end{array}$ & Japan & KY209 & $\begin{array}{l}\text { AY } 63048 \\
2\end{array}$ & $\begin{array}{l}\text { GU56934 } \\
1\end{array}$ & $\begin{array}{l}\text { GU56921 } \\
6\end{array}$ & $\begin{array}{l}\text { AB } 85690 \\
3\end{array}$ \\
\hline Isophanessp. & Japan & KY230 & $\begin{array}{l}\text { AY } 63048 \\
3\end{array}$ & $\begin{array}{l}\text { GU56934 } \\
2\end{array}$ & $\begin{array}{l}\text { GU56921 } \\
7\end{array}$ & $\begin{array}{l}\text { AB } 85690 \\
4\end{array}$ \\
\hline
\end{tabular}

\begin{tabular}{|l|l|l|l|l|l|l|}
\hline \multicolumn{2}{|c}{ Coryphacini } \\
\begin{tabular}{|l|l|l|l|} 
Coryphosmila \\
dolobrata
\end{tabular} & Japan & KY385 & AB85695 & AB85697 & AB85694 & AB85692 \\
\hline $\begin{array}{l}\text { Valenzuela } \\
\text { badiostigma }\end{array}$ & Japan & KY387 & AB85695 & AB85697 & AB85693 & AB85691 \\
\hline $\begin{array}{l}\text { Valenzuela flavidus } \\
\text { Valenzuela }\end{array}$ & USA & Vafla.8.31.2001.5 & AY63049 & GU56934 & GU56921 & AY27530 \\
\hline $\begin{array}{l}\text { kamakurensis } \\
\text { Valenzuela oyamai }\end{array}$ & Japan & KY223 & 9 & 3 & 8 & 8 \\
\hline
\end{tabular}

\begin{tabular}{|c|c|c|c|c|c|c|}
\hline \multicolumn{7}{|l|}{ Kodamaiini } \\
\hline $\begin{array}{l}\text { Genus (nr. } \\
\text { Austrocaecilius) sp. }\end{array}$ & Nepal & KY390 & $\begin{array}{l}\text { AB85695 } \\
8\end{array}$ & $\begin{array}{l}\text { AB85697 } \\
9\end{array}$ & $\begin{array}{l}\text { AB85694 } \\
3\end{array}$ & $\begin{array}{l}\text { AB85692 } \\
3\end{array}$ \\
\hline $\begin{array}{l}\text { Genus (nr. } \\
\text { Asiocaecilius or } \\
\text { Isophanopsis) sp. }\end{array}$ & $\begin{array}{l}\text { Malays } \\
\text { ia }\end{array}$ & KY382 & $\begin{array}{l}\text { AB85695 } \\
3\end{array}$ & $\begin{array}{l}\mathrm{AB} 85697 \\
4\end{array}$ & $\begin{array}{l}\text { AB85693 } \\
8\end{array}$ & $\begin{array}{l}\text { AB85691 } \\
8\end{array}$ \\
\hline Kodamaius sp. & Taiwan & KY393 & $\begin{array}{l}\text { AB85695 } \\
2\end{array}$ & $\begin{array}{l}\text { AB85697 } \\
3\end{array}$ & $\begin{array}{l}\text { AB85693 } \\
7\end{array}$ & $\begin{array}{l}\text { AB85691 } \\
7\end{array}$ \\
\hline $\begin{array}{l}\text { Pericaecilius } \\
\text { singularis }\end{array}$ & Taiwan & KY239 & $\begin{array}{l}\text { AY } 63049 \\
5\end{array}$ & $\begin{array}{l}\text { GU56934 } \\
0\end{array}$ & $\begin{array}{l}\text { GU56921 } \\
5\end{array}$ & $\begin{array}{l}\text { AB85691 } \\
4\end{array}$ \\
\hline $\begin{array}{l}\text { Fuellebornielinae } \\
\text { Fuelleborniella sp. }\end{array}$ & Ghana & $\begin{array}{l}\text { Fusp. } \\
11.24 .2003 .6\end{array}$ & $\begin{array}{l}\text { AY63049 } \\
6\end{array}$ & $\begin{array}{l}\text { GU56933 } \\
9\end{array}$ & $\begin{array}{l}\text { GU56921 } \\
4\end{array}$ & missing \\
\hline \multicolumn{7}{|l|}{ Paracaeciliinae } \\
\hline Enderleinella sp. & $\begin{array}{l}\text { Malays } \\
\text { ia }\end{array}$ & KY473 & $\begin{array}{l}\text { AB85696 } \\
1\end{array}$ & $\begin{array}{l}\text { AB85698 } \\
2\end{array}$ & $\begin{array}{l}\text { AB85694 } \\
5\end{array}$ & missing \\
\hline Enderleinella sp. & Peru & KY472 & $\begin{array}{l}\text { AB85696 } \\
2\end{array}$ & missing & $\begin{array}{l}\text { AB85694 } \\
6\end{array}$ & missing \\
\hline Paracaecilius japanus & Japan & KY233 & $\begin{array}{l}\text { AY } 63050 \\
1\end{array}$ & $\begin{array}{l}\text { AB85697 } \\
0\end{array}$ & $\begin{array}{l}\text { AB85693 } \\
4\end{array}$ & $\begin{array}{l}\text { AB85691 } \\
3\end{array}$ \\
\hline
\end{tabular}




\begin{tabular}{|l|l|l|l|l|l|l|}
$\begin{array}{l}\text { Xanthocaecilius } \\
\text { sommermanae }\end{array}$ & USA & $\begin{array}{l}\text { Xasom. } \\
8.31 .2001 .4\end{array}$ & AY63050 & GU56934 & GU56921 & AY13990 \\
\hline
\end{tabular}

\section{Outgroup}

\begin{tabular}{|c|c|c|c|c|c|c|}
\hline \multicolumn{7}{|c|}{ Ectopsocidae } \\
\hline $\begin{array}{l}\text { Ectopsocus } \\
\text { meridionalis }\end{array}$ & USA & Epmer.2.3.2001.4 & $\begin{array}{l}\text { AY } 63051 \\
2\end{array}$ & $\begin{array}{l}\text { GU56932 } \\
2\end{array}$ & $\begin{array}{l}\text { GU56919 } \\
7\end{array}$ & $\begin{array}{l}\text { AY } 27530 \\
0\end{array}$ \\
\hline Ectopsocus sp. & Japan & KY212 & $\begin{array}{l}\text { AY63051 } \\
0\end{array}$ & $\begin{array}{l}\mathrm{AB} 85696 \\
5\end{array}$ & $\begin{array}{l}\text { AB85692 } \\
6\end{array}$ & missing \\
\hline $\begin{array}{l}\text { Ectopsocopsis } \\
\text { cryptomeriae }\end{array}$ & USA & $\begin{array}{l}\text { Etcry. } \\
11.17 .2003 .2\end{array}$ & $\begin{array}{l}\text { AY63051 } \\
1\end{array}$ & $\begin{array}{l}\text { GU56932 } \\
3\end{array}$ & $\begin{array}{l}\text { GU56919 } \\
8\end{array}$ & missing \\
\hline
\end{tabular}

\section{Lachesillidae}

\begin{tabular}{|c|c|c|c|c|c|c|}
\hline $\begin{array}{l}\text { Anomopsocus } \\
\text { amabilis }\end{array}$ & USA & $\begin{array}{l}\text { Anama. } \\
11.17 .2003 .9\end{array}$ & $\begin{array}{l}\text { AY63050 } \\
9\end{array}$ & $\begin{array}{l}\text { GU56932 } \\
6\end{array}$ & $\begin{array}{l}\text { GU56920 } \\
1\end{array}$ & missing \\
\hline Eolachesilla chilensis & Chile & KY214 & $\begin{array}{l}\text { AY63051 } \\
4\end{array}$ & $\begin{array}{l}\text { GU56932 } \\
8\end{array}$ & $\begin{array}{l}\text { GU56920 } \\
3\end{array}$ & missing \\
\hline Lachesilla anna & USA & Laann.1.16.2001.2 & $\begin{array}{l}\text { AY63050 } \\
4\end{array}$ & missing & $\begin{array}{l}\text { AY27535 } \\
1\end{array}$ & $\begin{array}{l}\text { AY27530 } \\
1\end{array}$ \\
\hline Lachesilla forcepeta & USA & Lafor.8.31.2001.10 & $\begin{array}{l}\text { AY } 63050 \\
3\end{array}$ & $\begin{array}{l}\text { GU56932 } \\
7\end{array}$ & $\begin{array}{l}\text { GU56920 } \\
2\end{array}$ & $\begin{array}{l}\text { AB85689 } \\
8\end{array}$ \\
\hline Lachesilla sp. & $\begin{array}{l}\text { Malays } \\
\text { ia }\end{array}$ & KY229 & $\begin{array}{l}\text { AB85694 } \\
7\end{array}$ & $\begin{array}{l}\text { AB85699 } \\
4\end{array}$ & $\begin{array}{l}\text { AB85692 } \\
5\end{array}$ & missing \\
\hline
\end{tabular}

\section{Mesopsocidae}

\begin{tabular}{|l|l|l|l|l|l|l|}
$\begin{array}{l}\text { Idatenopsocus } \\
\text { orientalis }\end{array}$ & Japan & KY203 & $\begin{array}{l}\text { AY63051 } \\
3\end{array}$ & missing & AY13995 & AY13990 \\
$\begin{array}{l}\text { Mesopsocus } \\
\text { hongkongensis }\end{array}$ & Japan & KY224 & AY63051 & DQ10479 & DQ10476 & missing \\
\hline $\begin{array}{l}\text { Mesopsocus } \\
\text { unipunctatus }\end{array}$ & USA & $\begin{array}{l}\text { Meuni. } \\
12.4 .2003 .4\end{array}$ & $\begin{array}{l}\text { AY63051 } \\
5\end{array}$ & missing & AB85692 & missing \\
\hline
\end{tabular}

\section{Peripsocidae}

\begin{tabular}{|c|c|c|c|c|c|c|}
\hline Kaestneriella sp. & USA & Kasp.11.24.2003.5 & $\begin{array}{l}\text { AY } 63050 \\
6\end{array}$ & $\begin{array}{l}\text { GU56932 } \\
4\end{array}$ & $\begin{array}{l}\text { GU56919 } \\
9\end{array}$ & missing \\
\hline Peripsocus madidus & USA & $\begin{array}{l}\text { Pemad. } \\
8.31 .2001 .7\end{array}$ & $\begin{array}{l}\text { AY } 63050 \\
8\end{array}$ & missing & $\begin{array}{l}\text { AY } 27535 \\
2\end{array}$ & $\begin{array}{l}\text { AY27530 } \\
2\end{array}$ \\
\hline $\begin{array}{l}\text { Peripsocus } \\
\text { subfasciatus }\end{array}$ & USA & Pesub.2.3.2001.2 & $\begin{array}{l}\text { AY } 63050 \\
7\end{array}$ & $\begin{array}{l}\text { GU56932 } \\
5\end{array}$ & $\begin{array}{l}\text { GU56920 } \\
0\end{array}$ & $\begin{array}{l}\text { AY } 27530 \\
3\end{array}$ \\
\hline \multicolumn{7}{|c|}{ lipsocidae } \\
\hline Nepiomorpha sp. & $\begin{array}{l}\text { Malays } \\
\text { ia }\end{array}$ & KY200 & $\begin{array}{l}\text { AY63051 } \\
8\end{array}$ & missing & $\begin{array}{l}\text { AB85692 } \\
8\end{array}$ & missing \\
\hline
\end{tabular}



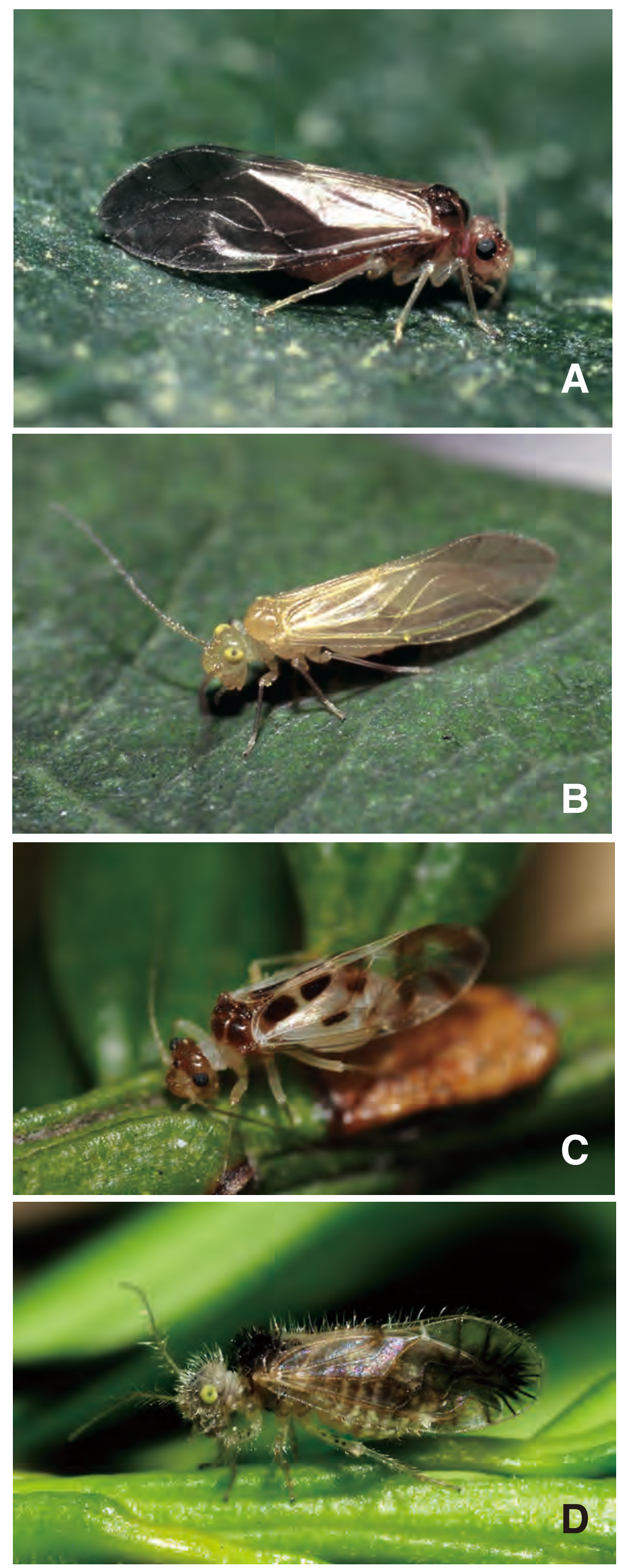


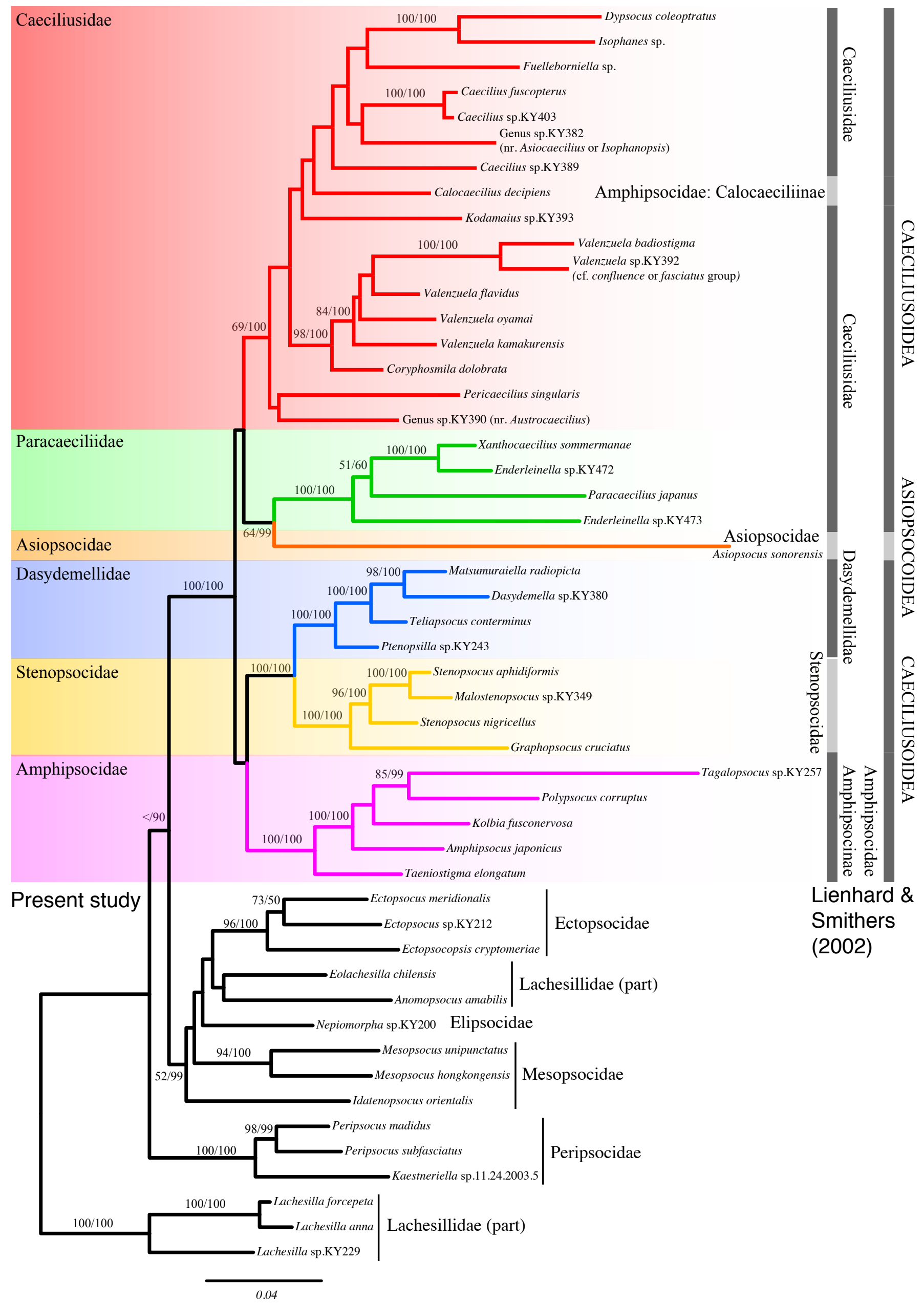

